\title{
Effect of Visfatin on Testosterone Hormone Level in Chronic Restraint Male Albino Rats
}

\author{
RADWA M. AL-SAYED, M.D. and SAFYA E. ESMAEEL, M.D. \\ The Department of Physiology, Faculty of Medicine, Zagazig University
}

\begin{abstract}
Background: Stress has been linked in many studies with infertility and hormonal irregularities. Visfatin is a novel adipocytokine which has been proven to decrease in chronic stress in rats.

Aim of Study: This study aimed at evaluation of the effect of visfatin in modulation of the complications of chronic restraint on gonadal functions.

Material and Methods: 32 male albino rats randomly allocated to four equal groups, group (I): Included rats fed a normal diet (control group) group (II): Included rats fed a normal diet for 2 months then received a single intraperitoneal 500 pmol visfatin injection group (III): Included immobilized rats (4hr/day) for 2 months and group (IV): Included immobilized rats (4hr/day) for 2 months then received a single intraperitoneal visfatin injection at a dose of 500pmol. After the last visfatin dose blood samples were collected and examined for testosterone, LH and FSH. Then laparotomy was conducted to dissect the right testis for histopathological studies.
\end{abstract}

Results: The restraint stress has inhibitory effects on male testosterone, LH, FSH and testicular tissues in rats, marked deterioration of gonadal functions in immobilization stress group (group III), a significant decrease $(p<0.001)$ in serum testosterone, $\mathrm{LH}$, sperm count and right testicular weights, marked deterioration in the gonadal histoarchitecture, but, there was a non-significant change in serum FSH. Exogenous visfatin administration in (group IV) significantly increased serum testosterone $(p<0.01)$, LH $(p<0.001)$, FSH $(p<0.01)$, and sperm count $(p<0.001)$ than group III, and markedly improved the gonadal histoarchitecture. Group II demonstrated results similar to group III when compared to the control group.

Conclusion: Visfatin plays a protective role against chronic stress-induced gonadal dysfunction via maintaining testicular steroidogenesis of Leydig cells.

Key Words: Visfatin - Chronic stress - Testicular function.

Correspondence to: Dr. Radwa M. Al-Sayed, E-Mail: radwa8066@yahoo.com

\section{Introduction}

CHRONIC stress is a condition that is induced by any stressor for a long period. Stress affects the physiological functions of the central nervous, cardiovascular, digestive, and neuroendocrine systems, as well as the reproductive system. Biochemical analysis has shown that the increased corticosterone and blood glucose levels are major markers of stress conditions [1]

Many reports have demonstrated that sexual disorders and infertility could result from psychological and physiological stresses [2,3] .

Regarding males, suffering stress may cause a significant reduction in the levels of testosterone, gonadotropin-releasing hormone, Follicle Stimulating Hormone (FSH) and Luteinizing Hormone (LH) $[\mathbf{2}, \mathbf{4 , 5}$, which could hinder the quality of sperms [5-7]. Additionally, they could also endure Leydig cell and seminiferous tubule damages $[\mathbf{5 , 8 , 9 ]}$.

Many reports have explained the downregulation of testosterone production which occurs in acute stress events and attributed it to the decreased level of steroidogenic proteins and enzymes such as Steroidogenic Acute Regulatory (StAR) protein and cytochrome $\mathrm{P} 450$ side-chain cleavage (CYP11A1) enzyme [10-12]

However, changes in sperm physiology and other testicular markers in conditions of stress require further explanation.

Fukuhara et al., [13] were the first to describe visfatin in 2005, its effect is similar to insulin as it decreases the serum glucose level via binding to insulin receptors, yet, does not compete with it as it binds to different sites. Its level rises after 
ingesting high-fat food which suggests that it serves a major role in the diet or obesity-induced insulin resistance [14] . It has been reported that visfatin significantly increases testosterone production [15] but its role in testicular steroidogenesis still vague.

Thus, this study aimed at evaluation of the effect of visfatin in the modulation of the complications of chronic restraint on gonadal functions.

\section{Material and Methods}

A group of 32 albino male rats (200-250g each) were obtained from the Animal House of Faculty of Veterinary Medicine, Zagazig University and kept in steel wire cages ( 8 rats per cage), with airconditioned room and adjusted lights at 12 hours light/12 hours dark cycle and temperature at 21$24^{\circ} \mathrm{C}$, food and water ad libitum was used for their nourishing.

They were randomly allocated to four equal groups:

1- Group I (control): Included 8 rats allowed to move freely in their cages without distribution nor stressors.

2- Group II (visfatin): Included 8 rats not subjected to stressors and received 500pmol single intraperitoneal visfatin injection (i.p) (Lyophilized without any additives, Sigma Aldrich Co. USA) [15] after 2 months from the onset of the experiment.

3- Group III (immobilization stress): Included 8 rats individually exposed to restraint sessions in special animal restraining metal cages adjustable to fit each rat. The restraining session involved placing the rats in the prone position at room temperature, 4h/day, 6 days/week for two months [4].

4- Group IV (visfatin + immobilization stress): Included 8 rats, exposed to similar restraining circumstances as group III and at the end of the restraining period ( 2 months) received 500pmol single intraperitoneal visfatin injection (i.p).

An approval was obtained for the study procedure from the Institutional Research Board of Faculty of Medicine, Zagazig University, and the study followed the guidelines for the care and use of research animals. Experiments were performed between 9:00AM and 4:00PM (from the 2 nd of January to 10th of March 2018).

\section{Blood collection:}

Clean plastic centrifuge tubes were used to collect the blood samples ( $8 \mathrm{ml} / \mathrm{rat})$ at the end of the experiment then left till clotted. Samples were then centrifuged for 15 minutes at a speed of 3000 rpm to separate the serum to be then collected by automatically operating pipettes with fine tips and kept at $-20^{\circ} \mathrm{C}$ till needed for analysis.

\section{Biochemical analysis:}

1-Rat Soluble visfatin, (recombinant): From Alexis Biochemicals, Axxora, USA.

2- Estimation of serum testosterone level: The technique of Tietz, (1995) was adopted using rat testosterone enzyme-linked immune-sorbent assay kit: (Catalog Number: 2011-11-5126, Shanghai Sun Red Biological Technology, China).

3- Estimation of serum LH level: The technique of Tietz, (1995) using rat luteinizing hormone (LH) enzyme-linked immunosorbent assay kit: (Catalog Number: 2011-11-0180, Shanghai Sunred Biological Technology, China).

4- Estimation of serum FSH level: The technique of Rebar et al., (1982) was adopted using rat follicle-Stimulating Hormone (FSH) enzymelinked immunosorbent assay kit: (Catalog Number: 2011-11-0183, Shanghai Sunred Biological Technology, China).

\section{Postmortem examination:}

The right testis of each animal was dissected then weighed, postmortem, by one hand and the other hand was used for a careful fat dissection [16].

\section{Spermatic parameters analysis:}

The epididymis of each testis was subjected to a dissection, as well as mincing in $2 \mathrm{ml}$ of Hank's Buffer Salt Solution (HBSS) at $37^{\circ} \mathrm{C},[17]$, then incubated for five minutes at $37^{\circ} \mathrm{C}$, then the standard hemocytometric technique was used for the analysis of the cauda epididymis sperm.

The White Blood Cell pipette (WBC pipette) was used to draw, up to the 0.5 mark, of the epididymal fluid and, up to the 11 mark of the semen diluting fluid (sodium bicarbonate $5 \mathrm{~g}$, formalin $1 \mathrm{ml}$, distilled water $99.0 \mathrm{ml}$ ), then both components were mixed thoroughly. One drop was placed in the hemocytometer chamber and the hemocytometer was kept in a humid environment (wet chamber) for one hour to allow the sperms to settle. Then the light microscope, at 400X, was used to count the sperms in the appropriate squares of the hemocytometer after the incubation. Sperm count $=$ No. of spermatozoa counted $\mathrm{X}$ dilution factor $\mathrm{X}$ volume factor/No. of areas counted was used to 
calculate the number of spermatozoa/ml fluid which refers to the sperm concentration [18]

\section{Histopathological examination:}

After collection of blood samples for hormonal analysis, each rat was subjected to a laparotomy to obtain the right testis for subsequent weighing and histopathological assessment as follows:

First, a careful removal of the tunica vaginalis followed by dissection of the testis, to be followed by cleaning using cold physiological saline to remove blood and any adherent tissue. Then a fixation was performed in $10 \%$ formaldehyde in fresh alcoholic bouin's fluid for 8 hours, then the sample was subjected to processing and embedding in paraffin wax, then sectioning at 5 thickness, and staining in hematoxylin-eosin. The light microscope was used to examine the sections to evaluate the histological features. The technique of $[19,20]$ was adopted for the histological assessment.

\section{Statistical analysis:}

SPSS program (Version 18 for windows) (SPSS Inc. Chicago, IL, USA) was used for statistical analysis and the obtained quantitative variables were expressed as mean \pm SD. Results of all groups were statistically compared using the One Way Analysis of Variance (ANOVA) then the LSD test. $p$-value $<0.05$ was considered statistically significant.

\section{Results}

Results showed that immobilized stressed male rats had a lower level of testosterone and $\mathrm{LH}$ than the control group (I) $(p<0.001)$, the difference was significant. Upon intake of visfatin, testosterone, LH, and FSH significantly increased in (group II) more than group I, $(p<0.01, p<0.001$ and $p<0.05$ respectively) moreover, group IV demonstrated a significantly higher testosterone, LH, and FSH than group III $(p<0.01, p<0.001$ and $p<0.01$ ) (Table 1).

Regarding the epididymal sperm count and right testicular weight, immobilized stressed male rats (group III) had a significantly lower count and weight than the control group $(p<0.001)$. Upon intake of visfatin, in groups (II \& IV) both parameters were significantly improved $(p<0.001)$ (Table 1).

Concerning, histopathological results, immobilized stressed male rats (group III) had irregular seminiferous tubules with atrophic walls, low count of sperm cells, and edematous interstitial tissue Fig. (1C). On the other hand, group II had highly regular seminiferous tubules with increased spermatogenesis at the level of spermatocytes Fig. (1B), group IV Fig. (1D) showed a markedly improved testicular histoarchitecture.

Table (1): Serum Testosterone, LH, FSH levels \& epididymal sperm count and right testicular weights in rats of all studied groups.

\begin{tabular}{|c|c|c|c|c|c|}
\hline Parameter & $(\mathrm{N}=8)$ & Group I & Group II & Group III & Group IV \\
\hline \multicolumn{6}{|c|}{ Serum testosterone levels $(\mathrm{ng} / \mathrm{ml})$ : } \\
\hline $\mathrm{X} \pm \mathrm{SD}$ & & $3.31 \pm 0.42$ & $3.98 \pm 0.29$ & $1.47 \pm 0.34$ & $2.03 \pm 0.35$ \\
\hline$p$-value of LSD & & & $p<0.01$ a & $p<0.001 \mathbf{a , b}$ & $p<0.001^{\mathbf{a}, \mathbf{b}}, p<0.01^{\mathbf{c}}$ \\
\hline \multicolumn{6}{|c|}{ Serum LH levels ( Uml): } \\
\hline $\mathrm{X} \pm \mathrm{SD}$ & & $1.44 \pm 0.08$ & $2.05 \pm 0.15$ & $1.13 \pm 0.12$ & $1.37 \pm 0.11$ \\
\hline$p$-value of LSD & & & $p<0.001 \mathrm{a}$ & $p<0.001$ a,b & $\mathrm{NS} \mathrm{a}, p<0.001 \mathbf{b}^{\prime} \mathbf{c}$ \\
\hline \multicolumn{6}{|c|}{ Serum FSH levels (Ul): } \\
\hline $\mathrm{X} \pm \mathrm{SD}$ & & $0.23 \pm 0.09$ & $0.48 \pm 0.07$ & 0.16 .02 & $0.26 \pm 0.06$ \\
\hline$p$-value of LSD & & & $p<0.05 \mathrm{a}$ & $\mathrm{NS}$ a,$p<0.001 \mathrm{~b}$ & $\mathrm{NS} \mathrm{a}, p<0.0011^{\mathrm{b}}, p<0.01 \mathrm{c}$ \\
\hline \multicolumn{6}{|c|}{ Epidydimal sperm count (millions/ml): } \\
\hline $\mathrm{X} \pm \mathrm{SD}$ & & $40.50 \pm 4.37$ & $61.12 \pm 9.09$ & $27.87 \pm 3.72$ & $39.50 \pm 4.72$ \\
\hline$p$-value of LSD & & & $p<0.001^{\text {a }}$ & $p<0.001 \mathbf{a , b}$ & $\mathrm{NS} \mathbf{a}, p<0.001 \mathbf{b}^{\prime} \mathbf{c}$ \\
\hline \multicolumn{6}{|c|}{ Right testicular wt (gm): } \\
\hline $\mathrm{X} \pm \mathrm{SD}$ & & $1.28 \pm 0.09$ & $1.56 \pm 0.10$ & $0.68 \pm 0.14$ & $1.15 \pm 0.14$ \\
\hline$p$-value of LSD & & & $p<0.001$ a & $p<0.001 \mathbf{a}, \mathbf{b}$ & $p<0.05 \mathbf{a}, p<0.001 \mathbf{b}, \mathbf{c}$ \\
\hline
\end{tabular}


Histopathological studies:
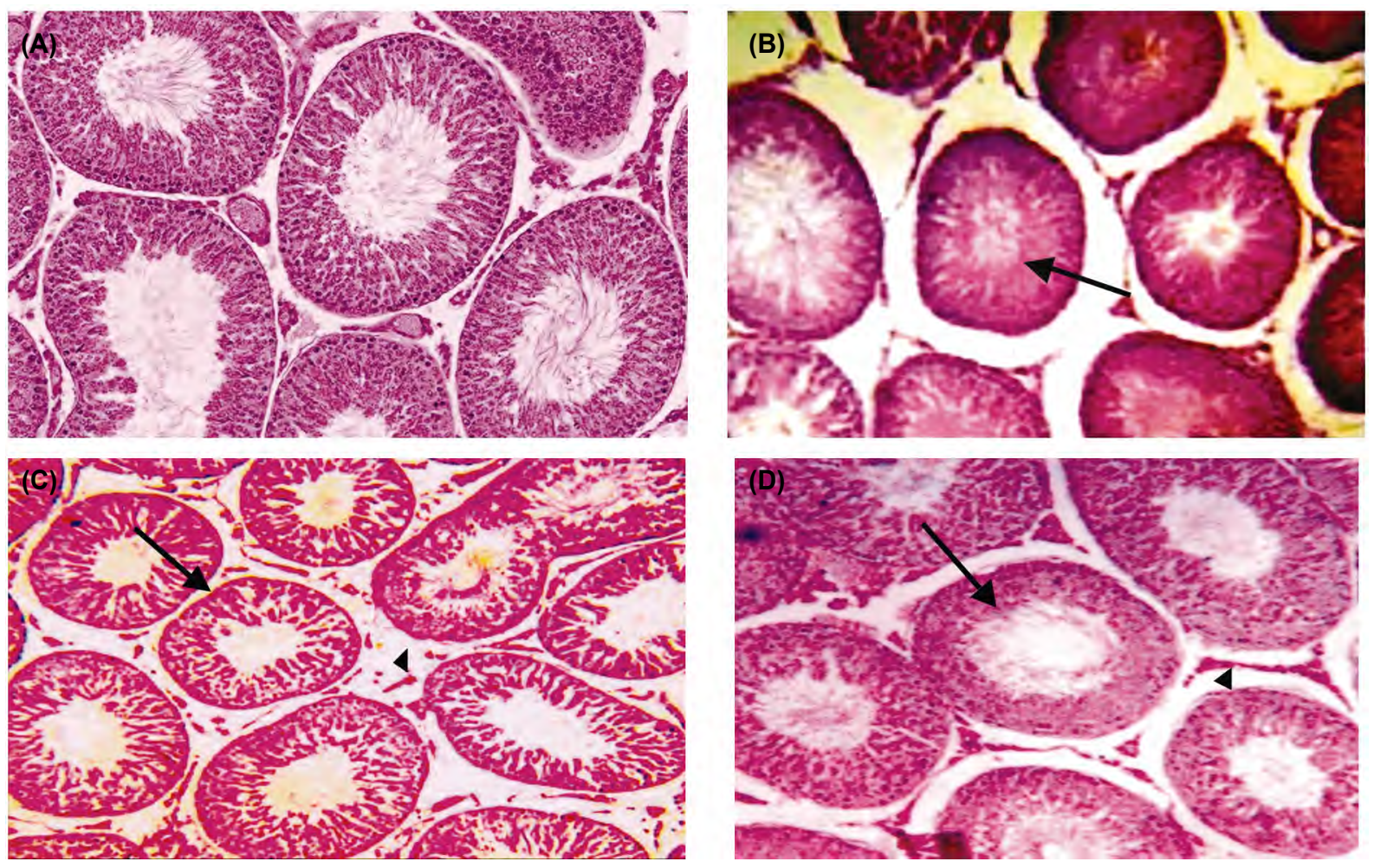

Fig. (1): Light photomicroscopic picture of right testis tissue stained by hematoxylin and eosin (H \& E) compared between groups. (A) Showing regular seminiferous tubules with advanced stages of cells spermatogenesis and normal intertubular gaps in the control group. (B) Showing highly regular seminiferous tubules and an increased spermatogenesis at the spermatocytes (arrow) level in visfatin treated group. (C) Showing irregular seminiferous tubules with atrophic walls and low count of sperm cells (arrow) as well as edematous interstitial tissue (pyramid) in immobilization stress. (D) Showing nearly equal seminiferous tubules in different stages of spermatogenesis (arrow). There is no edema in interstitial tissue (pyramid) in visfatin treated immobilization stress group (viewed under low power X200).

\section{Discussion}

It has been shown that many aspects of the body physiological functions are influenced by many types of stress such as immobilization which triggers alterations in reproductive functions [21]. Visfatin is an adipokine, excessively produced in visceral fat exhibiting insulin-like functions as it binds to the insulin receptors, which are located on Leydig cells yet at different sites than those belonging to the insulin $[\mathbf{1 3 , 2 2 , 2 3}$. Since insulin enhances testosterone synthesis and visfatin has an insulin-like action, thus visfatin could also increase testosterone level. Therefore, the target of the study in hands was to evaluate the effect of visfatin in the modulation of the complications of chronic restraint on gonadal functions [13,23-25]

Based on results of the current study, the serum level of testosterone, $\mathrm{LH}$, the number of sperms in the epididymis as well as the weight of the testis showed a significant reduction in immobilized stressed rates.
Similar studies have evaluated the consequences of various stress types on the fertility of both humans and animals and revealed that such stressors inhibit the testis and result in a reduction of the serum testosterone $[\mathbf{2 1 , 2 6 , 2 7 ]}$. Additionally, other studies revealed another mechanism of testosterone reduction in such cases which involves an inhibition of LHRH production and secretion from the hypothalamus which results from the depression of the LH serum level as a result of the stress [28]. Moreover, the aforementioned downregulation of the Hypothalamic-Pituitary-Gonad (HPG) axis could be caused by Corticotrophin-Releasing Factor (CRF) and endogenous opioids, mainly $\beta$ endorphins that are produced by the hypothalamus as a result of exposure to stress [29].

In addition, $\mathrm{CRF}$ and 3 -endorphins have been proved to affect the HPG axis via inhibition of hypothalamic production of LH-RH [30], depression of pituitary LH [31], and direct inhibition of testosterone formation in Leydig cells [32], which eventually lower the serum testosterone level. 
[27] reported that stress had an inhibitory effect on testosterone level which could be mediated by the endogenous opioid antagonist "Naltrexone".

[33] suggested that the decreased serum testosterone as a result of stress could be attributed to the intensive increase in the level of glucocorticoids as they downregulate the function of Leydig cell via downregulation of some enzymes which bind to glucocorticoid receptors such as NADPH P450 reductase, P45 0c 17 (17 $\alpha$-hydroxylase and 17, 20lyase) and 3(3-hydroxysteroid dehydrogenase [34]

Also, excessive glucocorticoids trigger apoptosis in Leydig cells resulting in a reduction in steroidogenesis which in turn decreases the serum level of testosterone $[\mathbf{2 8 , 3 5}]$

Moreover, stress stimulates the sympathetic nerves of the testis resulting in narrowing of the blood vessels and a decline in the blood supply which eventually causes a reduction in the serum testosterone [36].

$[37,38]$ assessed both catalase (CAT) \& Glutathione-S-Transferase (GST), which are essential for the protection against free radicals, in immobilized, stressed rats and reported a significant downregulation in serum level as well as the testicular level of both antioxidant enzymes.

CAT acts in synergism with Superoxide Dismutase (SOD) to eliminate the intracellular superoxide anions produced by NADPH-oxidase. They significantly reduce the membrane lipid peroxidation and oxidative stress [39]

Additionally, GST detoxifies the reactive lipid peroxides [38] . [33] reported that exposing rats to acute and chronic immobilization stress increases the level of serum testicular Malondialdehyde (MDA) resulting from the metabolism of polyunsaturated fatty acids, such process is a part of free radicals-induced cellular toxicity $[\mathbf{4 0 , 4 1 ]}$

To sum up, both downregulation of CAT and GST and the increased MDA level represent a case of oxidative stress and excessive free radicals, such fact has been documented in several previous studies as they reported that exposure to stress, of any type, triggered oxidative stress and its subsequent structural and functional tissue injuries caused by the increased formation of free radicals and Reactive Oxygen Species (ROS) [42,43].

These ROS have been shown to destroy most of the cellular macromolecules such as membrane polyunsaturated fatty acids, carbohydrates, proteins and DNA, causing impairment of cellular functions $[\mathbf{4 4 , 4 5}$. Polyunsaturated fatty acids are abundant in the testicular membrane rendering it vulnerable to oxidative stress [46], several studies have proved the drawbacks of the free radicals on testicular steroidogenesis [38] such as that Nitric Oxide (NO) free radicals which have been implicated in the stress-induced depression of testicular steroidogenesis and testosterone level in stressed immobilized rats $[37,46,47]$.

[47] conducted a study on stressed immobilized rats and found that they suffered a significant reduction of the testicular 3 (3-hydroxysteroid dehydrogenase, $17 \alpha$-hydroxylase/lyase (P450 C17) and NADPH-P450 reductase activities.

Additionally, [43] assessed testicular 3 (3 hydroxysteroid dehydrogenase and 17 (3 hydroxysteroid dehydrogenase in rats exposed to swimming exercise-induced oxidative stress and reported a significant downregulation of their activity.

On the contrary to the results of the study in hands, [48] reported that the serum LH did not decrease in stressed rats, and $[\mathbf{1 9 , 4 9 ]}$ reported that stress does not affect the reproductive function.

The serum FSH did not significantly change in the stressed immobilized rats of the present study and this could be owed to the short duration of the study.

According to the current study, an evident association was noticeable between visfatin administration and male gonadal functions demonstrated as a significant increase in the serum testosterone, LH, FSH, testicular weight \& and the number of sperms in the epididymis in both visfatin treated and immobilization stress groups compared to controls (I).

Similarly, [50] demonstrated in their study that the serum LH, FSH significantly increased followed by an increased release of testosterone from testicular Leydig cells. Also, [51] reported a similar finding in their study as they proved the insulinlike action of visfatin as it increases the serum $\mathrm{LH}$ and FSH and subsequently the testosterone level. Such effect could be served through two pathways, either directly via stimulation of testicular Leydig cells or indirectly via stimulation of the pituitary gland. The process of testosterone production is mediated mainly by pulses of LH, also, steroidogenesis which is conducted in Leydig cells is mediated locally by circulating hormones, growth factors, and cytokines [52] 
The status of the Hypothalamic-PituitaryGonadal (HPG) axis is reflected in the level of the serum testosterone, a plethora of stressors could lower the serum level of LH which in turn decreases the serum testosterone via downregulating the hypothalamic synthesis and secretion of LHRH [28]. Such stressors could also impair the functions of Leydig cell, specially steroidogenesis as a result of decreased hormonal levels and cytokines locally in the target cells and in fat cells $[28,35]$.

[15] demonstrated in their study that the secretion of testosterone from Leydig cells is directly proportionate to the level of $\mathrm{LH}$, as they incubated these cells with variable doses of $\mathrm{LH}[\mathbf{5 2 , 5 3}]$ also reported a similar finding.

Visfatin has a direct stimulatory effect on steroidogenesis Leydig cell and such role is served specifically at the step before the synthesis of pregnenolone. Such steps involved the transportation of cholesterol from the outer to the inner mitochondrial membrane by the steroidogenic acute regulatory (StAR) protein, and the use of cholesterol by cytochrome $\mathrm{P} 450$ side-chain cleavage enzyme (Cyt P450 scc). Visfatin cannot increase 25hydroxycholesterol stimulated steroidogenesis [15]

[15] reported that visfatin significantly increased the testosterone synthesis and release from Leydig cells in the presence of $\mathrm{LH} \mathrm{1,000} \mathrm{r]g}$.

Although, the intracellular mechanism of visfatin action is still vague. several researchers [54,55] have stressed upon the enzymatic mechanisms of testosterone production in the Leydig cell. Both protein kinase $\mathrm{C}$ (PKC) and protein kinase $\mathrm{A}$ (PKA) blocker downregulate the synthesis of testosterone, such effect is heightened when they are used in conjunction with visfatin which perform its action mainly via Ras/Raf1 kinase system and less through PKC and PKA system of enzymes [15].

Histopathological examination of the stressed immobilized group (III) of the current study demonstrated irregular seminiferous tubules with atrophic walls and low count of sperm cells as well as edematous interstitial tissues. Upon visfatin intake, testicular histoarchitecture significantly improved in both visfatin and immobilization stress treated groups.

Similarly, [15] demonstrated an enhancing action of visfatin on testosterone production which in turn stimulates spermatogenesis in most seminiferous tubules of the treated animals in comparison to their controls.

\section{Conclusion:}

Visfatin has a protective effect against immobilization stress-induced gonadal dysfunction, such effect is achieved via maintaining gonadal hormonal function through indirect and/or direct effect on the gonads. More investigations are essential to unveil the pathogenesis of these effects and to provide a novel therapy for stress-induced the reproductive disorders.

\section{Acknowledgment:}

The authors like to acknowledge and appreciate the effort of Prof. Dr. Kamal M. EL-Kashish; Professor of Pathology, Faculty of Medicine, Zagazig University, for performing the histopathological studies.

\section{References}

1- RETANA-MARQUEZ S., BONILLA-JAIME H., VAZQUEZ-PALACIOS G., MARTINEZ-GARCIA R. and VELAZQUEZ-MOCTEZUMA J.: Changes in masculine sexual behavior, corticosterone and testosterone in response to acute and chronic stress in male rats. Hormones and Behavior, 44 (4): 327-37, 2003.

2- KENNEDY S.H., DICKENS S.E., EISFELD B.S. and BAGBY R.M.: Sexual dysfunction before antidepressant therapy in major depression. Journal of affective disorders, 56 (2): 201-8, 1999.

3- BALDWIN D.S.: Depression and sexual dysfunction. British Medical Bulletin, 57 (1): 81-99, 2001.

4- RAI J., PANDEY S. and SRIVASTAVA R.: Testosterone hormone level in albino rats following restraint stress of long duration. J. Anat. Soc. India, 53 (1): 17-9, 2004.

5- ARUN S., BURAWAT J., SUKHORUM W., SAMPANNANG A., UABUNDIT N. and IAMSAARD S.: Changes of testicular phosphorylated proteins in response to restraint stress in male rats. Journal of Zhejiang UniversityScience B, 17 (1): 21-9, 2016.

6- FENSTER L., KATZ D.F., WYROBEK A.J., PIEPER C., REMPEL D.M., OMAN D., et al.: Effects of psychological stress on human semen quality. Journal of Andrology, 18 (2): 194-202, 1997.

7- CLARKE R.N., KLOCK S.C., GEOGHEGAN A. and TRAVASSOS D.E.: Relationship between psychological stress and semen quality among in-vitro fertilization patients. Human Reproduction, 14 (3): 753-8, 1999.

8- RAI J., PANDEY S. and SRIVASTAVA R.: Effect of immobilization stress on spermatogenesis of albino rats. J. Anat. Soc. India, 52 (1): 55-7, 2003.

9- HIRANO T., KOBAYASHI Y., OMOTEHARA T., TATSUMI A., HASHIMOTO R., UMEMURA Y., et al.: Unpredictable chronic stress-induced reproductive suppression associated with the decrease of kisspeptin immunoreactivity in male mice. Journal of Veterinary Medical Science, 76 (9): 1201-8, 2014.

10- MARTIN L.J. and TREMBLAY J.J.: Glucocorticoids antagonize cAMP-induced Star transcription in Leydig 
cells through the orphan nuclear receptor NR4A1. Journal of molecular endocrinology, 41 (3): 165-75, 2008.

11- STOJKOV N.J., JANJIC M.M., BJELIC M.M., MIHAJLOVIC A.I., KOSTIC T.S. and ANDRIC S.A.: Repeated immobilization stress disturbed steroidogenic machinery and stimulated the expression of cAMP signaling elements and adrenergic receptors in Leydig cells American Journal of Physiology-Endocrinology and Metabolism, 302 (10): E1239-E51, 2012.

12- LIN H., YUAN K.M., ZHOU H.Y., BU T., SU H., LIU S., et al.: Time-course changes of steroidogenic gene expression and steroidogenesis of rat Leydig cells after acute immobilization stress. International Journal of Molecular Sciences, 15 (11): 21028-44, 2014.

13- FUKUHARA A., MATSUDA M., NISHIZAWA M., SEGAWA K., TANAKA M., KISHIMOTO K., et al.: Visfatin: A protein secreted by visceral fat that mimics the effects of insulin. Science, 307 (5708): 426-30, 2005.

14- SETHI J.K. and VIDAL-PUIG A.: Visfatin: The missing link between intra-abdominal obesity and diabetes? Trends in Molecular Medicine, 11 (8): 344-7, 2005.

15- HAMEED W., YOUSAF I., LATIF R. and ASLAM M.: Effect of visfatin on testicular steroidogenesis in purified Leydig cells. Journal of Ayub Medical College Abbottabad, 24 (3-4): 62-4, 2012.

16-CASTEILLA L., PÉNICAUD L., COUSIN B. and CALISE D.: Choosing an adipose tissue depot for sampling. Adipose Tissue Protocols: Springer, p. 1-19, 2001.

17- IDRIS M.H.M., BUDIN S.B., OSMAN M. and MOHAMED J.: Protective role of Hibiscus sabdariffa calyx extract against streptozotocin induced sperm damage in diabetic rats. Excli Journal, 11: 659, 2012.

18- BELSEY M., MOGHISSI K., ELIASSON R., PAULSEN C., GALLEGOS A. and PRASAD M.: Laboratory manual for the examination of human semen and semen-cervical mucus interaction. Press Concern., 1-43, 1980.

19- MURTHY N.V.A., WRAY S.R., MELVILLE G.N., WYNTER H.H., NV S.R. and NV H.H.: Testicular function in rats following immobilization stress. Suppl. Int. J. Gynecol. Obstet., 26 (2): 297-29, 1988

20- RAGHAVENDRA V., TANGA F., RUTKOWSKI M.D., DeLEO J.A.: Anti-hyperalgesic and morphine-sparing actions of propentofylline following peripheral nerve injury in rats: Mechanistic implications of spinal glia and proinflammatory cytokines. Pain, 104 (3): 655-64, 2003.

21- AHMADI R., TAVAKOLI P. and MAFI M.: The effect of immobilization stress and Aloe vera extract on serum levels of LH, FSH and testosterone in male rats. Daneshvar., 19 (98): 69-74, 2012.

22- SAMAL B., SUN Y., STEARNS G., XIE C., SUGGS S and McNIECE I.: Cloning and characterization of the cDNA encoding a novel human pre-B-cell colonyenhancing factor. Molecular and Cellular Biology, 14 (2): 1431-7, 1994.

23- BEBAKAR W.M.W., HONOUR J.W., FOSTER D., LIU Y.L. and JACOBS H.S.: Regulation of testicular function by insulin and transforming growth factor- $\beta$. Steroids, 55 (6): 266-70, 1990.

24- LIN T., HASKELL J., VINSON N. and TERRACIO L.: Characterization of insulin and insulin-like growth factor
I receptors of purified Leydig cells and their role in steroidogenesis in primary culture: A comparative study. Endocrinology, 119 (4): 1641-7, 1986.

25- VARMA V., YAO-BORENGASSER A., RASOULI N., BODLES A.M., PHANAVANH B., LEE M.J., et al.: Human visfatin expression: relationship to insulin sensitivity, intramyocellular lipids, and inflammation. The Journal of Clinical Endocrinology \& Metabolism, 92 (2): 666-72, 2006.

26- RAZZOLI M., RONCARI E., GUIDI A., CARBONI L., ARBAN R., GERRARD P., et al.: Conditioning properties of social subordination in rats: Behavioral and biochemical correlates of anxiety. Hormones and behavior, 50 (2): 245-51, 2006

27- RETANA-MARQUEZ S., BONILLA-JAIME H., VAZQUEZ-PALACIOS G. and MARTINEZ-GARCIA R.: Naltrexone effects on male sexual behavior, corticosterone, and testosterone in stressed male rats. Physiology \& behavior, 96 (2): 333-42, 2009.

28- HARDY M.P., GAO H.B., DONG Q., GE R., WANG Q., CHAI W.R., et al.: Stress hormone and male reproductive function. Cell and tissue research, 322 (1): 147-53, 2005.

29- VACCARINO A.L. and KASTIN A.J.: Endogenous opiates: 1999. Peptides, 21 (12): 1975-2034, 2000.

30- BIDZINSKA B., PETRAGLIA F., ANGIONI S., GENAZZANI A.D., CRISCUOLO M., FICARRA G., et al.: Effect of Different Chronic Intermittent Stressors and Acetyl/-Carnitine on Hypothalamic [3-Endorphin and GnRH and on Plasma Testosterone Levels in Male Rats. Neuroendocrinology, 57 (6): 985-90, 1993.

31- MARIC' D., KOSTIC' T. and KOVACEVIC' R.: Effects of acute and chronic immobilization stress on rat Leydig cell steroidogenesis. The Journal of steroid biochemistry and molecular biology, 58 (3): 351-5, 1996.

32- KOSTIC' T., ANDRIC' S., MARIC' D. and KOVA CEVIC R.: The effect of acute stress and opioid antagonist on the activity of NADPH-P450 reductase in rat Leydig cells. The Journal of steroid biochemistry and molecular biology, 66 (1-2): 51-4, 1998

33- AL-DAMEGH M.A.: Stress-induced changes in testosterone secretion in male rats: Role of oxidative stress and modulation by antioxidants. Open Journal of Animal Sciences, 4 (02): 70, 2014.

34- DONG Q., SALVA A., SOTTAS C.M., NIU E., HOLMES M. and HARDY M.P.: Rapid glucocorticoid mediation of suppressed testosterone biosynthesis in male mice subjected to immobilization stress. Journal of Andrology, 25 (6): 973-81, 2004.

35- GAO H.B., TONG M.H., HU Y.Q., GUO Q.S., GE R. and HARDY M.P.: Glucocorticoid induces apoptosis in rat leydig cells. Endocrinology, 143 (1): 130-8, 2002.

36- KRAUTH M.T., SIMONITSCH I., AICHBERGER K.J., MAYERHOFER M., SPERR W.R., SILLABER C., et al. Immunohistochemical detection of VEGF in the bone marrow of patients with chronic myeloid leukemia and correlation with the phase of disease. American Journal of Clinical Pathology, 121 (4): 473-81, 2004.

37- JANA K., SAMANTA P. and GHOSH D.: Dose-dependent response to an intratesticular injection of calcium chloride for induction of chemosterilization in adult albino rats. 
Veterinary Research Communications, 26 (8): 651-73, 2002.

38- MANNA I., JANA K. and SAMANTA P.: Effect of intensive exercise-induced testicular gametogenic and steroidogenic disorders in mature male Wistar strain rats: A correlative approach to oxidative stress. Acta Physiologica., 178 (1): 33-40, 2003.

39- POWERS S.K., JI L.L. and LEEUWENBURGH C.: Exercise training-induced alterations in skeletal muscle antioxidant capacity: A brief review. Medicine and science in sports and exercise, 31 (7): 987-97, 1999.

40- DEBNATH D. and MANDAL T.K.: Study of quinalphos (an environmental oestrogenic insecticide) formulation (Ekalux 25 EC)-induced damage of the testicular tissues and antioxidant defence systems in Sprague-Dawley albino rats. Journal of Applied Toxicology: An International Journal, 20 (3): 197-204, 2000.

41- OJO O., KABUTU F., BELLO M. and BABAYO U.: Inhibition of paracetamol-induced oxidative stress in rats by extracts of lemongrass (Cymbropogon citratus) and green tea (Camellia sinensis) in rats. African Journal of Biotechnology, 5 (12): 1227-32, 2006.

42- MADRIGAL J.L., OLIVENZA R., MORO M.A., LIZASOAIN I., LORENZO P., RODRIGO J., et al.: Glutathione depletion, lipid peroxidation and mitochondrial dysfunction are induced by chronic stress in rat brain. Neuropsychopharmacology, 24 (4): 420, 2001.

43- MANNA I., JANA K. and SAMANTA P.K.: Intensive swimming exercise-induced oxidative stress and reproductive dysfunction in male Wistar rats: Protective role of a-tocopherol succinate. Canadian Journal of Applied Physiology, 29 (2): 172-85, 2004.

44- YANG C.Y. and LIN M.T.: Oxidative stress in rats with heatstroke-induced cerebral ischemia. Stroke, 33 (3): 7904, 2002.

45- TAYLOR J.M. and CRACK P.J.: Impact of oxidative stress on neuronal survival. Clinical and Experimental Pharmacology and Physiology, 31 (7): 397-406, 2004.

46- GHOSH D., DAS U., GHOSH S., MALLICK M. and DEBNATH J.: Testicular gametogenic and steroidogenic activities in cyclophosphamide treated rat: A correlative study with testicular oxidative stress. Drug and chemical toxicology, 25 (3): 281-92, 2002.

47- KOSTIC T.S., ANDRIC S.A., MARIC D. and KOVACEVIC R.Z.: Inhibitory effects of stress-activated nitric oxide on antioxidant enzymes and testicular steroidogenesis. The Journal of steroid biochemistry and molecular biology, 75 (4-5): 299-306, 2000.

48- NEMOTO T., IWASAKI-SEKINO A., YAMAUCHI N. and SHIBASAKI T.: Role of urocortin 2 secreted by the pituitary in the stress-induced suppression of luteinizing hormone secretion in rats. American Journal of PhysiologyEndocrinology and Metabolism, 299 (4): E567-E75, 2010.

49- ANDERSEN M.L., BIGNOTTO M., MACHADO R.B. and TUFIK S.: Different stress modalities result in distinct steroid hormone responses by male rats. Brazilian Journal of Medical and Biological Research, 37 (6): 791-7, 2004.

50- BRÜNING J.C., GAUTAM D., BURKS D.J., GILLETTE J., SCHUBERT M., ORBAN P.C., et al.: Role of brain insulin receptor in control of body weight and reproduction. Science, 289 (5487): 2122-5, 2000.

51- BURCELIN R.M., THORENS B., GLAUSER M., GAILLARD R.C. and PRALONG F.O.P.: Gonadotropinreleasing hormone secretion from hypothalamic neurons: Stimulation by insulin and potentiation by leptin. Endocrinology, 144 (10): 4484-91, 2003.

52- SAEZ J.M.: Leydig cells: Endocrine, paracrine, and autocrine regulation. Endocrine reviews, 15 (5): 574-626, 1994.

53- SAEZ J., AVALLET O., NAVILLE D., PERRARDSAPORI M. and CHATELAIN P.: Sertoli-Leydig Cell Communications. Annals of the New York Academy of Sciences, 564 (1): 210-31, 1989.

54- CLARK B.J., WELLS J., KING S.R. and STOCCO D.M.: The purification, cloning, and expression of a novel luteinizing hormone-induced mitochondrial protein in MA-10 mouse Leydig tumor cells. Characterization of the steroidogenic acute regulatory protein (StAR). Journal of Biological Chemistry, 269 (45): 28314-22, 1994.

55- STOCCO D.M. and CLARK B.J.: Regulation of the acute production of steroids in steroidogenic cells. Endocrine reviews, 17 (3): 221-44, 1996. 


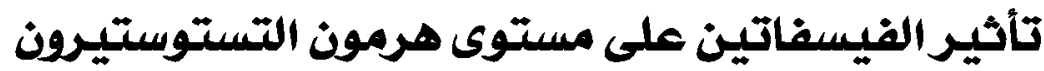

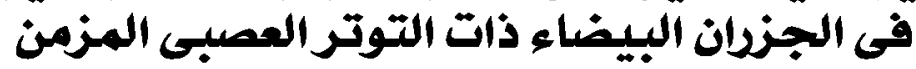

خلفية البحث والهدف منه: لقد تم الريط بين التوتر العصبى المزمن فى العديد من الدراسات مع العقم والإضطرابات الهرمونية. ولقد

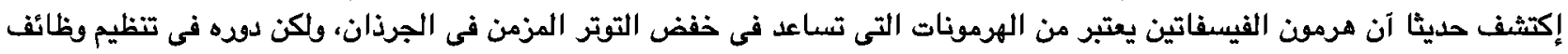

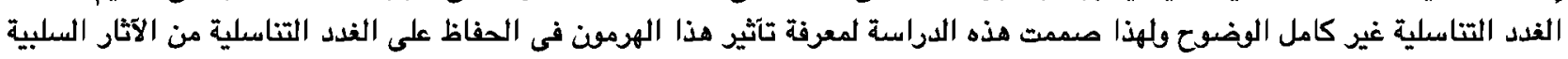
الناتجة عن التوتر المزمن.

مواد وطرق البحث: آجريث هذه الدراسة على عدد إثنين وثلاثين من ذكور الجرذان البيضاء البالغة والتى تم تقسيمها عشوائيا إلى آريع مجموعات متساوية: • المجموعدة الآولى : تم تغذيتها على الفذاء الطبيعى لمدة شهرين. • المجموعدة الثانية: مجموعة لدراسة تآثير هرمون الفيسفاتين فقد قمنا بتغذيتها بالغذاء الطبيعى لمدة شهرين ثم إعطاؤها هرمون الفيسفاتين

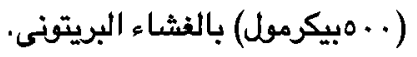

• المجموعدة الثالثة: مجموعة لدراسة تآثير التوتر المزمن، والقد قمنا بإحداثه عن طريق منع الحركة ع ساعات متتالية يوميا لمدة شهرين.

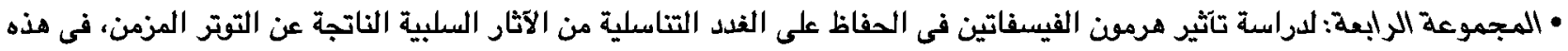

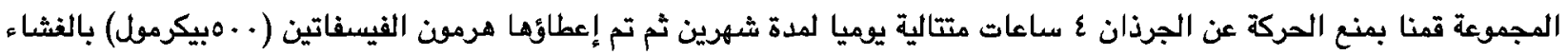
البريتونى.

$$
\text { وقد آسفرت نتائج هذا البحث عن: }
$$

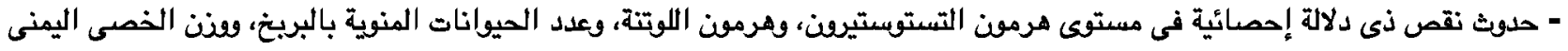

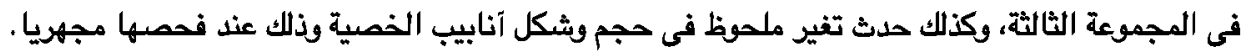

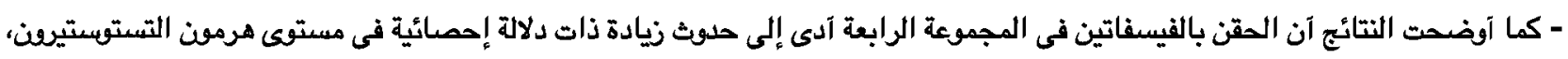
وهرمون اللوتنة، والهرمون المحفز لجريبات المبيض، وعدد الحيوانات المنوية بالبريخ، وقذن الخصى اليمنى عند مقارنتها بالمجموعة الثالثة. - كما آن الحقن بالفيسفاتين فى المجموعة الثانية آدى إلى تغيرات مماثلة لما تم ذكره سالفا فى المجموعة الرابعة عند مقارنتها بالمجموعة

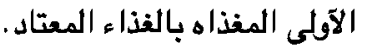

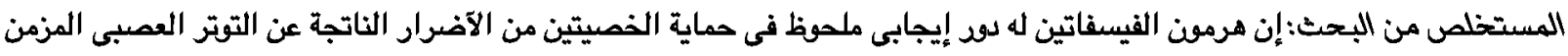
وذلك عن طريق زيادة الهرمونات المحفزة للغدد الجنسية هرمنية. ومن نتائج هذا البحث يمكن آن نوصى بعمل المزيد من الدراسات لبحث التآثير العلاجى لهرمون الفيسفاتين لهالات الخلل في وظائف الغدد الفيد التناسلية الناتج عن التوتر العصبي المزمن. 